\title{
Insulin secretion and insulin sensitivity in diabetic and non-diabetic subjects with hepatic nuclear factor- $1 \alpha$ (maturity-onset diabetes of the young-3) mutations
}

\author{
Martine Vaxillaire ${ }^{1}$, Maria E Pueyo ${ }^{2}$, Karine Clément ${ }^{1}$, Jean Fiet $^{3}$, José Timsit $^{4}$, Jacques Philippe ${ }^{5}$, \\ Jean-Jacques Robert ${ }^{6}$, Luc Tappy ${ }^{7}$, Philippe Froguel $^{1,8}$ and Gilberto Velho ${ }^{2}$ \\ ${ }^{1}$ CNRS EP-10, Institut Pasteur de Lille, and ${ }^{8} \mathrm{CHU}$ de Lille, Lille, France, ${ }^{2}$ INSERM U-342, Hôpital Saint Vincent de Paul, Paris, France, \\ ${ }^{3}$ Laboratoire de Biologie Hormonale. Hôpital Saint-Louis, Paris, France, ${ }^{6}$ Unité de Diabetologie de l'enfant et de l'adolescent and ${ }^{4}$ Service \\ d'Immunologie Clinique, Hôpital Necker-Enfants Malades, Paris, France, ${ }^{5}$ Unité de Diabétologie Clinique, Hôpital Cantonal Universitaire, \\ Geneva, Switzerland and ${ }^{7}$ Institut de Physiologie, Université de Lausanne, Lausanne, Switzerland
}

(Correspondence should be addressed to G Velho, INSERM U-342, Hôpital Saint Vincent de Paul, 82 Avenue Denfert Rochereau, 75014 Paris, France; Email: gvelho@infobiogen.fr)

\begin{abstract}
Objective: To evaluate insulin secretion and sensitivity in affected (diabetes mellitus or impaired glucose tolerance; $n=7$ ) and in unaffected (normal glucose tolerance; $n=3$ ) carriers of hepatocyte nuclear factor- $1 \alpha$ (maturity-onset diabetes of the young-3 (MODY3)) gene mutations.

Methods: Insulin secretion was assessed by an i.v. glucose tolerance test (IVGTT), hyperglycemic clamp and arginine test, and insulin sensitivity by an euglycemic hyperinsulinemic clamp. Results were compared with those of diabetic MODY2 (glucokinase-deficient) and control subjects.

Results: The amount of insulin secreted during an IVGTT was decreased in affected MODY3 subjects $(46 \pm 24$ (s.D.) $\mathrm{pmol} / \mathrm{kg}$ body weight $(\mathrm{BW}))$ as compared with values in MODY2 $(120 \pm 49 \mathrm{pmol} / \mathrm{kg}$ $\mathrm{BW})$ and control $(173 \pm 37 \mathrm{pmol} / \mathrm{kg} \mathrm{BW} ; P=0.0004)$ subjects. The amount of insulin secreted during a $10 \mathrm{mmol} / \mathrm{l}$ glucose clamp was decreased in affected MODY 3 subjects $(171 \pm 78 \mathrm{pmol} / \mathrm{kg} \mathrm{BW})$ and MODY2 subjects $(302 \pm 104 \mathrm{pmol} / \mathrm{kg} \mathrm{BW})$ as compared with control subjects $(770 \pm 199 \mathrm{pmol} / \mathrm{kg}$ $\mathrm{BW} ; \mathrm{P}=0.0001)$. Insulin secretion in response to arginine was decreased in affected MODY 3 subjects. Milder and heterogeneous defects were observed in the unaffected MODY3 subjects; the amount of insulin secreted during the hyperglycemic clamp was $40-79 \%$ of that of controls. The response to arginine was abnormally delayed. Insulin sensitivity was decreased in diabetic but not in non-diabetic MODY3 subjects.

Conclusions: Beta-cell dysfunction in response to glucose and arginine is observed in affected and unaffected MODY3 subjects. The MODY3 and MODY2 subtypes present different insulin secretion profiles. Secondary insulin resistance might contribute to the chronic hyperglycemia of MODY3 patients and modulate their glucose tolerance.
\end{abstract}

European Journal of Endocrinology $141609-618$

\section{Introduction}

Maturity-onset diabetes of the young (MODY) is an autosomal dominant subtype of non-insulin-dependent diabetes mellitus (NIDDM), characterized by early age of onset (1). MODY is genetically heterogeneous and so far mutations in five genes on chromosomes 20q, $7 \mathrm{p}$, $12 \mathrm{q}, 13 \mathrm{q}$ and 17 have been shown to cause MODY. These genes encode the transcription factor hepatocyte nuclear factor $4-\alpha(H N F-4 \alpha / M O D Y 1)(2,3)$, the enzyme glucokinase (GCK/MODY2) $(4,5)$, and the transcription factors HNF- $1 \alpha(H N F-1 \alpha / M O D Y 3)(6,7)$, insulin promoter factor-1 (IPF1) (8) and HNF-1 $\beta /$ TCF 2
(9) respectively. About 15-25\% of MODY families show no mutations in these loci suggesting that at least one additional locus remains to be identified (10). The genetic heterogeneity of MODY is associated with clinical and metabolic heterogeneity (1). Mutations in GCK/MODY2 result in mild chronic hyperglycemia due to reduced pancreatic beta-cell responsiveness to glucose, and decreased net accumulation of hepatic glycogen and increased hepatic gluconeogenesis following meals $(5,11-13)$. In contrast, MODY1 and MODY3 are characterized by major hyperglycemia associated with microvascular complications $(14,15)$. Data on IPF1- and HNF-1 $\beta$-related diabetes are scarce. 
$\mathrm{HNF}-1 \alpha$ is a transcription factor involved in tissuespecific expression of many genes in the liver, kidney, the endocrine and exocrine pancreas, and a variety of other tissues $(16,17)$. However, the target genes responsible for the MODY3 phenotype and the mechanisms implicated in the hyperglycemia remain unclear. We and others have shown that MODY3 is associated with a beta-cell defect $(15,18,19)$. The present report describes detailed evaluations of insulin secretion and insulin sensitivity in individuals carrying $H N F-1 \alpha$ mutations who have a range of glucose tolerance from normal to impaired to NIDDM.

\section{Methods}

\section{Subjects}

The MODY kindreds participating in the present study belong to a cohort of Caucasian families with multiple cases of diabetes collected for the study of the genetic determinants of the different types of diabetes mellitus (DM) (20). All kindreds are of French ancestry, except FS4, which is of Swiss ancestry. A 75-g oral glucose tolerance test (OGTT) was performed in 18 heterozygous carriers of HNF-1 $\alpha$ mutations from nine different MODY3 kindreds, and in 27 unaffected first-degree relatives, homozygous for the wild-type allele, who were used as a control group (7). Subjects with HNF-1 $\alpha$ mutations had normal glucose tolerance (NGT; $n=4$ ), impaired glucose tolerance (IGT; $n=4)$ or DM $(n=10)$ according to criteria of the World Health Organization (21). Basic demographic and clinical data of family members are shown in Table 1. Evaluations of insulin secretion and insulin sensitivity by an i.v. glucose tolerance test (IVGTT), arginine test and glucose clamps were then performed in ten carriers of HNF-1 $\alpha$ mutations from six kindreds, who accepted these evaluations. They had NGT $(n=3)$, IGT $(n=2)$ or DM $(n=5)$. Patients were divided into two groups according to the glucose tolerance status: one group consisted of the seven hyperglycemic individuals with IGT or DM (affected MODY3 subjects), and the other group consisted of the three subjects with NGT (unaffected MODY3 subjects). HNF-1 $\alpha$ mutations in these subjects were G31D (subject M3\#10), R55G56fsdelGAGGG (M3\#3 and M3\#4), Y122C (M3\#2 and M3\#6), S142F (M3\#1, M3\#7 and M3\#8), R171X (M3\#5) and P291fsdelC (M3\#9). Eleven healthy individuals, unrelated to the patients and with no diabetic relatives, were used as controls for these evaluations of insulin secretion and insulin sensitivity. Affected MODY3 subjects were also compared with a group composed of six diabetic carriers of GCK/MODY 2 mutations. Data from the diabetic MODY2 subjects have been partially reported previously $(12,22)$. Profiles of the basic demographic and clinical data of patients and controls who underwent these metabolic investigations are shown in Table 2. All subjects were in good general health; those with diabetes had no evidence of diabetic complications. All diabetic subjects were treated by sulfonylurea and subjects M3\#1 and M3\#5 also received biguanides. As not all of the 18 carriers of HNF-1 $\alpha$ mutations tested by OGTT accepted the additional metabolic evaluations, we have also estimated the beta-cell function from the OGTT data (see below). Subjects were compared with normoglycemic first-degree relatives, carriers of wildtype alleles. All subjects participating in the study gave written informed consent.

Table 1 Demographic and clinical profile of family members: OGTT studies. Data expressed as mean \pm S.D. Statistics are Kruskal-Wallis test ( $P$ values) followed by Tukey-Kramer HSD test when appropriate. Sex was compared with a contingency table chi-square test.

\begin{tabular}{|c|c|c|c|c|c|}
\hline & \multicolumn{3}{|c|}{ MODY3 subjects } & \multirow{2}{*}{$\begin{array}{l}\text { First-degree } \\
\text { relatives }^{a}\end{array}$} & \multirow[b]{2}{*}{$\boldsymbol{P}$} \\
\hline & DM & IGT & NGT & & \\
\hline Subjects $(n)$ & 10 & 4 & 4 & 27 & - \\
\hline $\operatorname{Sex}(M / F)$ & $5 / 5$ & $1 / 3$ & $4 / 0$ & $15 / 12$ & 0.15 \\
\hline Age (years) & $42 \pm 10$ & $22 \pm 7$ & $32 \pm 11$ & $34 \pm 10$ & 0.04 \\
\hline Body mass index $\left(\mathrm{kg} / \mathrm{m}^{2}\right)$ & $22.9 \pm 1.1$ & $21.9 \pm 1.6$ & $25.4 \pm 6.9$ & $22.7 \pm 3.0$ & 0.74 \\
\hline Fasting glucose $(\mathrm{mmol} / \mathrm{l})$ & $8.7 \pm 3.2^{*}$ & $5.0 \pm 0.4$ & $5.6 \pm 0.4$ & $5.1 \pm 0.5$ & $<0.003$ \\
\hline Fasting insulin $(\mathrm{pmol} / \mathrm{l})$ & $40 \pm 28$ & $45 \pm 38$ & $48 \pm 19$ & $42 \pm 37$ & 0.77 \\
\hline 2-h glucose $(\mathrm{mmol} / \mathrm{l})$ & $16.1 \pm 4.8^{*}$ & $9.2 \pm 1.3^{*}$ & $5.4 \pm 1.1$ & $5.7 \pm 1.2$ & $<0.0001$ \\
\hline 2-h insulin $(\mathrm{pmol} / \mathrm{l})$ & $80 \pm 67$ & $123 \pm 116$ & $140 \pm 118$ & $172 \pm 115$ & 0.11 \\
\hline Relative insulin response $(\mathrm{l} / \mathrm{mmol})^{\mathrm{b}}$ & $0.23 \pm 0.21 *$ & $1.03 \pm 1.01^{*}$ & $1.85 \pm 1.18$ & $2.86 \pm 2.46$ & $<0.0001$ \\
\hline Triglycerides (mmol/l) & $0.74 \pm 0.21$ & $0.79 \pm 0.17$ & $1.04 \pm 0.49$ & $0.90 \pm 0.39$ & 0.48 \\
\hline Total cholesterol $(\mathrm{mmol} / \mathrm{l})$ & $5.20 \pm 1.05$ & $5.12 \pm 0.30$ & $4.53 \pm 0.10$ & $5.09 \pm 0.94$ & 0.74 \\
\hline High density lipoprotein cholesterol ( $\mathrm{mmol} / \mathrm{l})$ & $1.41 \pm 0.23$ & $1.26 \pm 0.28$ & $1.20 \pm 0.23$ & $1.49 \pm 0.45$ & 0.50 \\
\hline Low density lipoprotein cholesterol (mmol/l) & $3.45 \pm 0.98$ & $3.50 \pm 0.60$ & $2.86 \pm 0.45$ & $3.12 \pm 0.79$ & 0.56 \\
\hline
\end{tabular}

* Statistically significant differences $(P<0.05)$ as compared with the unaffected relatives.

a Normoglycemic homozygous carriers of wild-type alleles.

b $(\Delta 30-0 \mathrm{~min}$ insulin/ $\Delta 30-0 \mathrm{~min}$ glucose $) /$ basal insulin. 
Table 2 Demographic and clinical profile of subjects and controls from insulin secretion and insulin sensitivity studies. Data expressed as mean \pm S.D. Statistics are Kruskall-Wallis test ( $P$ values) followed by Tukey-Kramer HSD test when appropriate (see Methods). Sex was compared with a contingency table chi-square test. Data from the three unaffected MODY3 subjects are not included in the statistics.

\begin{tabular}{|c|c|c|c|c|c|c|c|}
\hline & Sex & $\begin{array}{c}\text { Age } \\
\text { (years) }\end{array}$ & $\begin{array}{c}\text { BMI } \\
\left(\mathrm{kg} / \mathrm{m}^{2}\right)\end{array}$ & $\begin{array}{c}\text { Age of diagnosis } \\
\text { (years) }\end{array}$ & $\begin{array}{c}\text { Hb } \mathbf{A 1} \mathbf{C}^{\mathrm{a}} \\
(\%)\end{array}$ & $\begin{array}{c}\text { FPG }^{\mathrm{b}} \\
(\mathrm{mmol} / \mathrm{l})\end{array}$ & $\begin{array}{l}2 \mathrm{hPG}^{\mathrm{b}} \\
(\mathrm{mmol} / \mathrm{l})\end{array}$ \\
\hline Affected MODY3 subjects & $2 \mathrm{M} / 5 \mathrm{~F}$ & $30 \pm 11$ & $22.6 \pm 2.6$ & $15 \pm 3$ & $6.4 \pm 1.3$ & $7.7 \pm 2.0^{*}$ & $13.2 \pm 4.2^{*}$ \\
\hline Unaffected MODY3 subjects & $3 \mathrm{M} / 0 \mathrm{~F}$ & $31 \pm 7$ & $23.8 \pm 4.0$ & - & $5.2 \pm 0.1$ & $5.1 \pm 0.3$ & $4.7 \pm 1.2$ \\
\hline Control group & $6 \mathrm{M} / 5 \mathrm{~F}$ & $28 \pm 4$ & $21.5 \pm 1.6$ & - & - & $4.8 \pm 0.5$ & $4.8 \pm 1.0$ \\
\hline MODY2 subjects & $5 \mathrm{M} / 1 \mathrm{~F}$ & $34 \pm 10$ & $21.5 \pm 2.7$ & $16 \pm 3$ & $6.2 \pm 0.2$ & $7.9 \pm 0.3^{*}$ & $10.7 \pm 0.9^{*}$ \\
\hline Statistical significance $(P)$ & 0.14 & 0.46 & 0.50 & 0.67 & 0.72 & 0.0008 & 0.0008 \\
\hline
\end{tabular}

* Statistically significant differences $(P<0.05)$ as compared with the control group.

${ }^{a} \mathrm{Hb}$ A1C: glycated hemoglobin A1C; standard values in our laboratory for non-diabetic subjects: $4.9 \pm 0.7 \%$.

${ }^{\mathrm{b}} \mathrm{FPG}$ and $2 \mathrm{hPG}$ stand for fasting and 2-h plasma glucose, respectively, during an OGTT.

\section{Study design}

Insulin secretion and insulin sensitivity were evaluated during two experimental protocols performed less than 1 week apart. The first protocol involved the measurements of insulin secretory responses during an IVGTT, hyperglycemic clamp and i.v. injection of arginine. The second protocol consisted of an euglycemic hyperinsulinemic clamp to assess insulin action. These evaluations were performed at the Clinical Immunology Department, Hôpital Necker-Enfants Malades, Paris, France, except for subject M3\#9 who was studied at the Division of Clinical Physiology, University Medical Center, Lausanne, Switzerland. Subject preparation and blood sampling details were described previously (23).

Insulin secretory responses during IVGTT, hyperglycemic clamp and arginine administration The IVGTT was performed in all subjects with MODY-3 mutations and the hyperglycemic clamp and the arginine test were performed in nine out of the ten subjects. Following a 20-min baseline sampling period, all subjects received a bolus of $30 \%$ dextrose $(0.5 \mathrm{~g} / \mathrm{kg}$ body weight (BW)) over exactly 3 min. Completion of glucose administration was marked as time 0 . From time 15 to $120 \mathrm{~min}$, a hyperglycemic clamp was performed during which plasma glucose was clamped at $10 \mathrm{mmol} / \mathrm{l}$ by means of a variable rate i.v. infusion of $30 \%$ dextrose (Infusomat, Secura Braun, Melsungen, Germany). Plasma glucose concentration was determined at 5-min intervals and the glucose infusion rate was automatically adjusted by a microcomputer using algorithms previously described (24). In order to standardize the prevailing level of glycemia for the arginine test (25), the arginine bolus was administered at the end of the glucose clamp: at time $120 \mathrm{~min}, 5 \mathrm{~g}$ of $10 \%$ arginine chlorhydrate was injected i.v. in $30 \mathrm{~s}$ and sampling was continued for an additional $15 \mathrm{~min}$.

Euglycemic hyperinsulinemic clamp This test was performed in seven out of the ten MODY-3 subjects. After a 30-min baseline sampling period, insulin
(Actrapid, Novo-Nordisk Industry, Copenhagen, Denmark) was administered as a primed continuous infusion for $2 \mathrm{~h}$ with a priming dose of $10 \mathrm{mU} / \mathrm{kg} \mathrm{BW}$ and an infusion rate of $1 \mathrm{mU} / \mathrm{kg} \mathrm{BW}$ per min. Plasma glucose concentration was determined at 5-min intervals and the rate of an i.v. 30\% dextrose infusion (Infusomat) was automatically adjusted by a microcomputer to maintain plasma glucose at a pre-set level of $4.7 \mathrm{mmol} / \mathrm{l}(24)$.

Assays Throughout the experiments, blood was regularly sampled for glucose, insulin and C-peptide measurements. Plasma glucose was measured by the glucose oxidase technique (Beckman II analyzer, Beckman, Fullerton, CA, USA). Plasma insulin and plasma C-peptide were measured by RIAs. Crossreactivity with intact pro-insulin is at least 30\% for insulin and 15\% for C-peptide assays.

\section{Data analysis}

OGTT Beta-cell function in response to the oral ingestion of $75 \mathrm{~g}$ glucose was quantified as the ratio of the incremental plasma insulin response above basal at $30 \mathrm{~min}$ to that of plasma glucose, divided by basal plasma insulin levels $((\Delta 30-0 \mathrm{~min}$ insulin $/ \Delta 30-0 \mathrm{~min}$ glucose)/basal insulin), as previously described $(26,27)$. This measure of insulin secretion was termed 'relative insulin response'.

IVGTT, hyperglycemic clamp and arginine test First-phase insulin secretion following an IVGTT was expressed as the respective sum of insulin and C-peptide values of 1 and $3 \mathrm{~min}$. Hyperglycemic clamp results are expressed as the average insulin and C-peptide values from 60 to $120 \mathrm{~min}$. Responses to arginine were expressed as the incremental area above the value at time $120 \mathrm{~min}$ of insulin and C-peptide, calculated by the trapezoidal rule using values at 122, 123, 124, 125 and $130 \mathrm{~min}$. During the study period, insulin secretion rates (ISRs; pmol/kg BW per min) were computed 
for each 1-min interval from time 0 to $20 \mathrm{~min}$, and for each 2-min interval thereafter (see below). The amount of insulin (pmol/kg BW) secreted during the IVGTT (0-10 min), hyperglycemic clamp (60-120 min) and arginine test (120-130 min) was computed from the estimated ISR during these periods.

Estimations of ISR ISRs were derived by deconvolution of the plasma C-peptide concentrations (28) using version 3.4a of the ISEC software (29). Individual kinetics parameters of C-peptide clearance are computed by ISEC from standard kinetic parameters (30), taking into account the age, sex, body surface area and glucose tolerance status of the subject.

Euglycemic hyperinsulinemic clamp Average values of plasma glucose and insulin, and of glucose infusion rates during the last $30 \mathrm{~min}$ of the clamp (90-120 min) were used in the calculations. Glucose clearance was computed by dividing the average glucose infusion rate $(\mathrm{mmol} / \mathrm{kg} \mathrm{BW}$ per $\mathrm{min})$ by the average plasma glucose concentration (mmol/l) (31). Insulin sensitivity was expressed as an insulin sensitivity index (ISI) computed as the ratio glucose clearance/plasma insulin concentration, multiplied by $10^{6}(\mu \mathrm{l} / \mathrm{kg}$ BW per min per $\mathrm{pmol} / \mathrm{l}$ insulin). Two unaffected MODY3 subjects were not tested with an euglycemic hyperinsulinemic clamp, and ISI was then computed with data from the hyperglycemic clamp (90-120 min), as this represents an adequate alternative for individuals with preserved insulin secretion (32). The use of glucose clearance, instead of glucose infusion rates, in the computation of ISI minimizes the bias related to different mass action effects of plasma glucose at different glucose levels (euglycemia vs hyperglycemia) on rates of glucose disposal (31).

Statistical analysis Data are expressed as mean \pm standard deviation (s.D.) unless stated otherwise. A Kruskal-Wallis test (rank sums) for non-parametric data was used for comparisons between groups. When this test was significant, comparisons between pairs were made using the Tukey-Kramer HSD test with log-transformed data (33). Qualitative traits were analyzed by contingency table chi-square tests. Individual and/or average data are given in the text, tables and figures for the group of unaffected MODY3 subjects, but the data were not included in the statistics due to the small size of the group. For summarizing the responses of each subject to the different tests of insulin secretion and action described above, individual tests were considered normal when values were higher than 1 S.D. below the mean of controls for the respective test, moderately decreased $(\downarrow)$ when values were between 1 and 2 s.D. below the mean of controls, and severely decreased ( $\downarrow$ ) when lower than 2 s.D. below the mean of controls. These computations were performed with data normalized by log-transformation. A conservative approach was used and both the insulin and C-peptide results, as well as the amount of secreted insulin computed from the ISR, when appropriate, had to be abnormal to deem the test result abnormal. Statistics were performed with JMP software (SAS Institute Inc., Cary, NC, USA).

\section{Results}

\section{OGTT}

The relative insulin response following the oral ingestion of glucose was significantly lower in MODY3 subjects with DM $(0.23 \pm 0.21 \mathrm{l} / \mathrm{mmol})$ or IGT $(1.03 \pm$ $1.01 \mathrm{l} / \mathrm{mmol}$ ) than in their normoglycemic firstdegree relatives, carriers of wild-type alleles $(2.86 \pm$ 2.46 l/mmol; Kruskal-Wallis $P<0.0001$; Table 1). The response in unaffected MODY3 subjects was decreased but not significantly different from that of the normoglycemic wild-type relatives $(1.85 \pm 1.18 \mathrm{l} / \mathrm{mmol})$.

\section{IVGTT and hyperglycemic clamp}

Fasting plasma glucose was significantly higher in affected MODY3 and in MODY2 subjects than in controls, while fasting insulin and C-peptide concentrations were not significantly different in any of the groups (Table 3). Plasma glucose levels peaked $1 \mathrm{~min}$ after the injection of an i.v. glucose bolus, showing a trend towards higher levels in affected MODY3 subjects and in MODY2 subjects than in controls $(P=0.06)$. The first-phase insulin secretion was lower in diabetic MODY3 subjects than in subjects from the other groups. Insulin and C-peptide values at 1 and $3 \mathrm{~min}$, as well as the amount of insulin secreted from 0 to $10 \mathrm{~min}$ computed from the ISR, were significantly decreased as compared with values in control subjects (Table 3 and Fig. 1). C-peptide values at 1 and $3 \mathrm{~min}$ and the amount of insulin secreted from 0 to $10 \mathrm{~min}$ in affected MODY3 subjects were also significantly lower than values in MODY2 subjects, while insulin values at 1 and $3 \mathrm{~min}$, although decreased, failed to reach significance. The first-phase insulin secretion was well preserved in unaffected MODY3 subjects. When considering insulin and C-peptide values at 1 and $3 \mathrm{~min}$ and the amount of insulin secreted from 0 to $10 \mathrm{~min}$, at least one of these parameters was normal (higher than 1 s.D. below the mean of the controls) in all unaffected MODY3 subjects (Table 3 and Fig. 1).

From time 60 to $120 \mathrm{~min}$ of the hyperglycemic clamp study, plasma glucose concentrations were $12.4 \pm 1.6,10.5 \pm 0.8$ and $10.1 \pm 0.5 \mathrm{mmol} / \mathrm{l}$ in affected MODY3, MODY2 and control subjects respectively $(P=0.04)$, and were $10.7 \pm 0.7 \mathrm{mmol} / \mathrm{l}$ in unaffected MODY3 subjects. Concomitant mean plasma insulin and C-peptide values, as well as the amount of insulin 
Table 3 IVGTT, hyperglycemic clamp and arginine test. Data are mean \pm S.D. Insulin and C-peptide $(90-120$ min) during the hyperglycemic clamp represent the mean \pm S.D values of samples obtained at 60,80,90,100,110 and $120 \mathrm{~min}$. Statistics are Kruskall-Wallis test ( $P$ values) followed by Tukey-Kramer HSD test when appropriate (see Methods). Data from the three unaffected MODY3 subjects are not included in the statistics.

\begin{tabular}{|c|c|c|c|c|c|c|c|c|c|c|}
\hline \multirow[b]{2}{*}{$\begin{array}{l}\text { Subjects } \\
\text { (glucose tolerance status) }\end{array}$} & \multicolumn{6}{|c|}{ IVGTT } & \multicolumn{2}{|c|}{ Hyperglycemic clamp } & \multicolumn{2}{|c|}{ Arginine test } \\
\hline & $\begin{array}{l}\text { Glucose } \\
\text { O min } \\
(\mathrm{mmol} / \mathrm{l})\end{array}$ & $\begin{array}{l}\text { Insulin } \\
0 \mathrm{~min} \\
(\mathrm{pmol} / \mathrm{l})\end{array}$ & $\begin{array}{l}\text { C-peptide } \\
0 \mathrm{~min} \\
(\mathrm{nmol} / \mathrm{l})\end{array}$ & $\begin{array}{l}\text { Glucose } \\
\text { peak } \\
(\mathrm{mmol} / \mathrm{l})\end{array}$ & $\begin{array}{l}\text { Insulin } \\
1+3 \mathrm{~min} \\
(\mathrm{pmol} / \mathrm{l})\end{array}$ & $\begin{array}{l}\text { C-peptide } \\
1+3 \mathrm{~min} \\
(\mathrm{nmol} / \mathrm{l})\end{array}$ & $\begin{array}{c}\text { Insulin } \\
60-120 \text { min } \\
\text { (pmol/l) }\end{array}$ & $\begin{array}{l}\text { C-peptide } \\
60-120 \mathrm{~min} \\
(\mathrm{nmol} / \mathrm{l})\end{array}$ & $\begin{array}{c}\text { Insulin } \\
\text { area } \\
(\mathrm{pmol} / \mathrm{l} \times \mathrm{min})\end{array}$ & $\begin{array}{c}\text { C-peptide } \\
\text { area } \\
(\mathrm{nmol} / \mathrm{I} \times \min )\end{array}$ \\
\hline M3\#1 (DM) & 12.1 & 12 & 0.35 & 28.4 & 18 & 0.42 & $23 \pm 6$ & $0.58 \pm 0.08$ & 768 & 5.15 \\
\hline M3\#2 (DM) & 7.2 & 42 & 0.51 & 21.9 & 240 & 1.79 & - & - & - & - \\
\hline M3\#3 (DM) & 8.6 & 12 & 0.32 & 26.7 & 60 & 0.75 & $20 \pm 4$ & $0.34 \pm 0.07$ & 450 & 2.89 \\
\hline M3\#4 (DM) & 9.9 & 12 & 0.58 & 25.5 & 42 & 1.38 & $30 \pm 7$ & $0.66 \pm 0.22$ & 912 & 3.86 \\
\hline M3\#5 (DM) & 9.3 & 28 & 0.54 & 21.4 & 60 & 1.22 & $28 \pm 3$ & $0.73 \pm 0.10$ & 510 & 5.25 \\
\hline M3\#6 (IGT) & 5.2 & 30 & 0.44 & 15.2 & 114 & 1.06 & $70 \pm 5$ & $1.01 \pm 0.07$ & 1236 & 4.15 \\
\hline M3\#7 (IGT) & 5.7 & 54 & 0.75 & 19.6 & 246 & 1.75 & $58 \pm 11$ & $0.88 \pm 0.09$ & 3780 & 9.10 \\
\hline M3\#8 (NGT) & 4.1 & 18 & 0.41 & 14.9 & 756 & 3.53 & $95 \pm 10$ & $1.53 \pm 0.07$ & 4476 & 9.77 \\
\hline M3\#9 (NGT) & 5.1 & 44 & 0.57 & 21.2 & 264 & 3.34 & $194 \pm 77$ & $2.72 \pm 0.44$ & - & - \\
\hline M3\#10 (NGT) & 5.2 & 38 & 0.83 & 22.9 & 444 & 3.59 & $170 \pm 22$ & $2.53 \pm 0.22$ & 1950 & 5.05 \\
\hline Affected MODY3 subjects & $8.3 \pm 2.4^{*}$ & $27 \pm 17$ & $0.50 \pm 0.15$ & $22.7 \pm 4.6$ & $111 \pm 94^{*}$ & $1.20 \pm 0.50^{\star \#}$ & $39 \pm 22^{*}$ & $0.70 \pm 0.24^{*}$ & $1276 \pm 1259^{*}$ & $5.07 \pm 2.16^{\star}$ \\
\hline Unaffected MODY3 subjects & $4.8 \pm 0.6$ & $33 \pm 14$ & $0.60 \pm 0.21$ & $19.7 \pm 4.2$ & $488 \pm 249$ & $3.49 \pm 0.13$ & $153 \pm 50$ & $2.26 \pm 0.64$ & - & - \\
\hline Control group & $5.0 \pm 0.3$ & $44 \pm 19$ & $0.72 \pm 0.31$ & $18.5 \pm 3.0$ & $799 \pm 353$ & $3.97 \pm 0.81$ & $286 \pm 92$ & $2.74 \pm 0.45$ & $4471 \pm 2411$ & $10.69 \pm 2.61$ \\
\hline MODY2 subjects & $7.1 \pm 0.5^{\star}$ & $30 \pm 12$ & $0.50 \pm 0.22$ & $21.2 \pm 2.8$ & $429 \pm 246^{*}$ & $3.08 \pm 1.26$ & $74 \pm 54^{*}$ & $1.23 \pm 0.28^{*}$ & $1416 \pm 414^{*}$ & $7.56 \pm 1.75$ \\
\hline Statistical significance $(P)$ & 0.0003 & 0.14 & 0.13 & 0.06 & 0.0004 & 0.0007 & 0.0002 & 0.0001 & 0.0015 & 0.006 \\
\hline
\end{tabular}

Symbols represent statistically significant differences $(P<0.05)$ as compared with the control group $\left(^{*}\right)$, and MODY2 subjects $(\#)$. 
$\mathbf{A}$
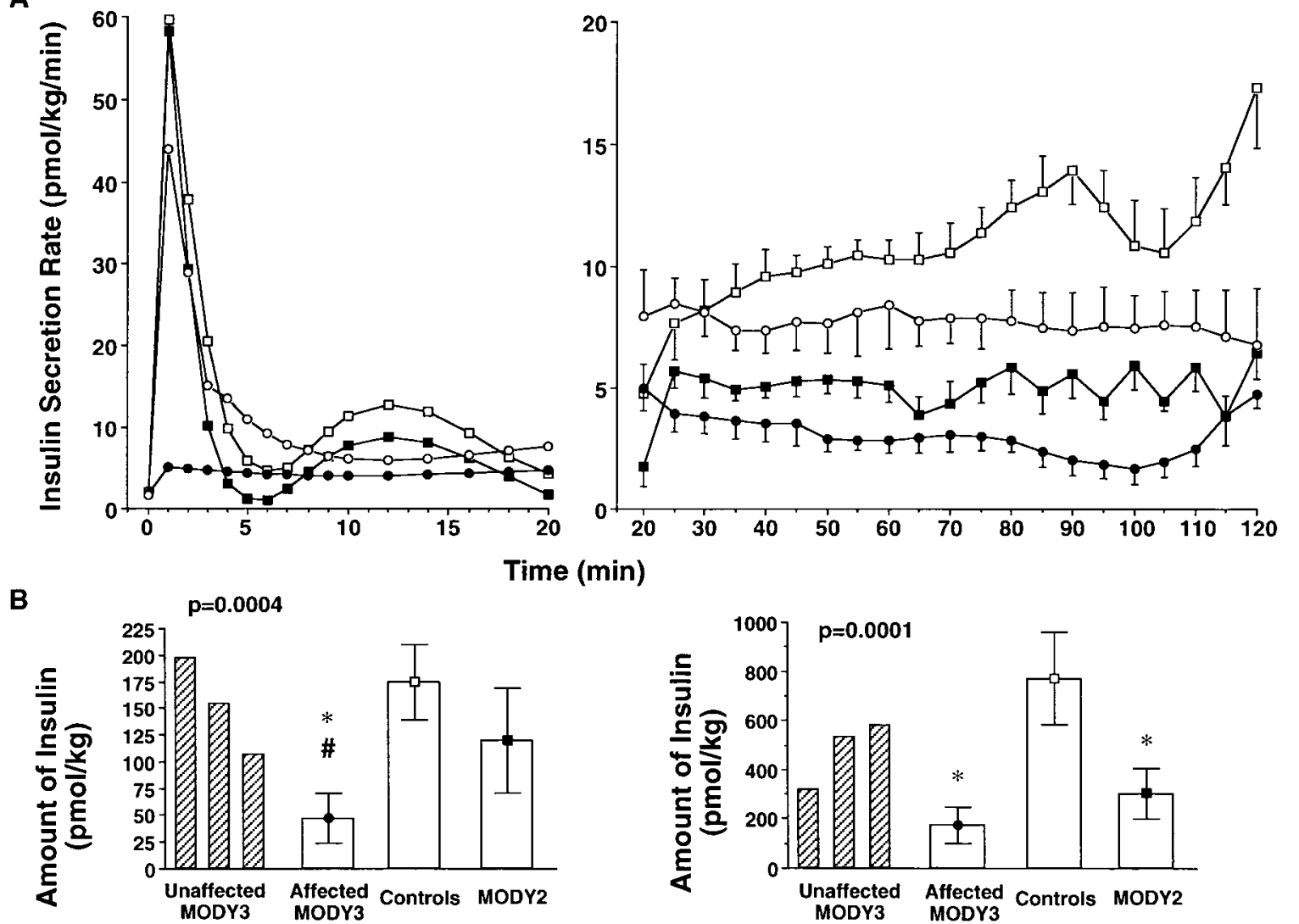

Figure 1 (A) ISRs during the IVGTT (0-20 min) and hyperglycemic clamp (20-120 min) in affected MODY3 (๑), unaffected MODY3 (O), MODY2 ( $\square$ ) and control ( $\square$ ) subjects. Results expressed as mean (IVGTT) or mean \pm S.E.M. (hyperglycemic clamp) for the sake of clarity. (B) Amount of insulin secreted during the IVGTT $(0-10 \mathrm{~min})$ and hyperglycemic clamp $(90-120 \mathrm{~min})$. Results expressed as mean \pm S.D. or individual data (hatched bars) for unaffected MODY3 subjects. Statistics are the Kruskal-Wallis test ( $P$ values) followed by a TukeyKramer HSD test for comparison between pairs when appropriate; the symbols represent statistically significant differences $(P<0.05)$ as compared with the control group $\left(^{*}\right)$ and MODY2 subjects (\#).

secreted during this time-interval computed from ISRs, were greatly decreased in affected MODY3 subjects, and moderately but significantly decreased in MODY2 subjects as compared with controls (Table 3 and Fig. 1). The three unaffected MODY3 subjects showed heterogeneous responses. When considering mean plasma insulin and C-peptide values, and the amount of insulin secreted during the hyperglycemic clamp, one subject presented decreased responses (lower than 2 S.D. below the average of controls), while the remaining two subjects presented at least one of these parameters within the normal range (higher than 1 s.D. below the mean of the controls).

\section{Arginine test}

At the end of the hyperglycemic clamp (time $120 \mathrm{~min}$ ), plasma glucose was $10.8 \pm 1.2,9.8 \pm 0.2$ and $10.0 \pm$ $0.3 \mathrm{mmol} / \mathrm{l}$ in affected MODY3, MODY2 and control subjects respectively $(P<0.04)$, and was $10.2 \pm$ $0.8 \mathrm{mmol} / \mathrm{l}$ in unaffected MODY3 subjects. Concomitant plasma insulin values were $41 \pm 26,78 \pm 64,339 \pm 118$
$(P<0.0002)$ and $139 \pm 48 \mathrm{pmol} / \mathrm{l} ; \mathrm{C}$-peptide values were $0.69 \pm 0.28, \quad 1.14 \pm 0.30, \quad 3.08 \pm 0.62 \quad(P<$ $0.0001)$ and $2.28 \pm 0.73 \mathrm{nmol} / \mathrm{l}$ respectively in affected MODY3, MODY2, control subjects and unaffected MODY3 subjects. To account for the observed heterogeneity of plasma insulin and C-peptide values, the responses to the arginine test were expressed as the increment over levels at time $120 \mathrm{~min}$. The area under the insulin curve, computed from time 120 to $130 \mathrm{~min}$, was significantly reduced in affected MODY3 and MODY2 subjects as compared with controls, while the area under the $\mathrm{C}$-peptide curve was significantly reduced only in affected MODY3 subjects (Table 3 ). The amount of insulin secreted in response to arginine was computed from time 120-130 min from the increment in ISR over levels at time $120 \mathrm{~min}$ (Fig. 2). The levels in affected MODY3 subjects were significantly reduced as compared with those in controls, while MODY2 subjects had well-preserved responses. Here again, when excluding the two affected MODY3 subjects with IGT, the responses of the remaining five affected MODY3 subjects with DM were significantly lower than those of 
A
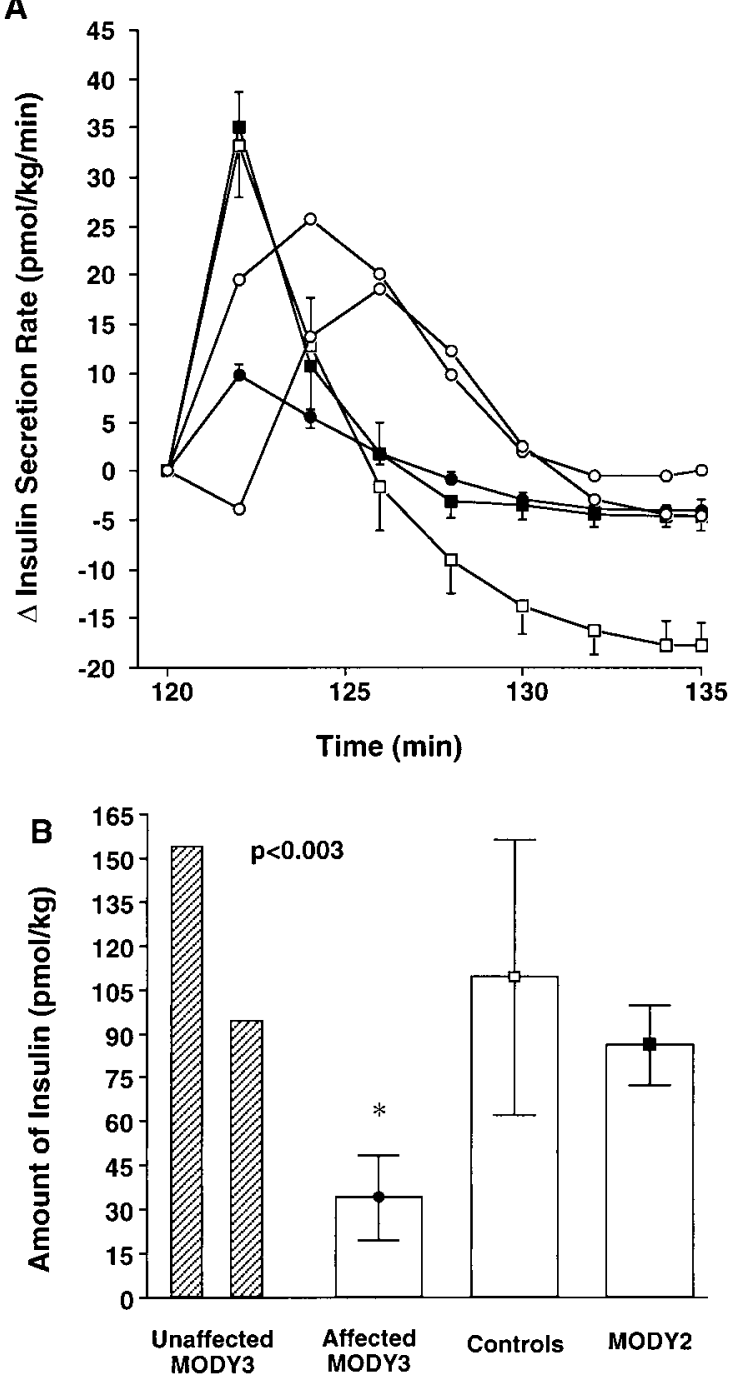

Figure 2 (A) Increase in ISR over the 120 min value during the i.v. arginine test in affected MODY3 $(\bullet)$, unaffected MODY3 (O), MODY2 ( $\square$ ) and control ( $\square$ ) subjects. Results expressed as mean \pm S.E.M. for the sake of clarity. (B) Amount of insulin secreted during the arginine test (120-130 min). Results expressed as mean \pm S.D. or individual data (hatched bars) for unaffected MODY3 subjects. Statistics are the Kruskal-Wallis test ( $P$ value) followed by a Tukey-Kramer HSD test for comparison between pairs when appropriate; the symbols represent statistically significant differences $(P<0.05)$ as compared with the control group $\left(^{*}\right)$.

the MODY2 subjects who all had DM (data not shown). The two unaffected MODY3 subjects who were tested had quantitatively normal responses (Table 3, Fig. 2). However, insulin secretion in response to arginine was delayed in both individuals as compared with subjects in the other groups (Fig. 2).

\section{Hyperinsulinemic euglycemic clamp}

Average plasma glucose values observed from 90 to $120 \mathrm{~min}$ were $4.7 \pm 0.1 \mathrm{mmol} / \mathrm{l}$ for affected MODY3

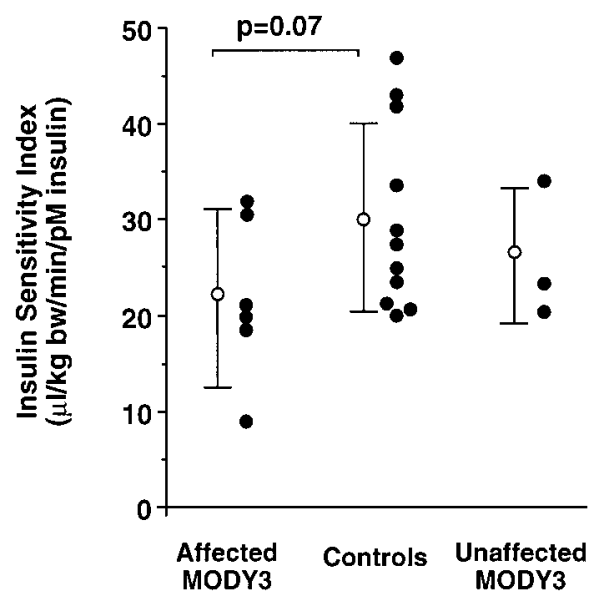

Figure 3 ISI in affected MODY3, unaffected MODY3 and control subjects. Results computed from data of the euglycemic hyperinsulinemic clamp, except for two unaffected MODY3 subjects, for whom it was computed from data of the hyperglycemic clamp (see Methods). Results expressed as individual values (0) and group mean \pm S.D. ( $\bigcirc)$.

subjects and $4.8 \pm 0.3 \mathrm{mmol} / \mathrm{l}(P=0.84)$ for control subjects. Insulin values were $334 \pm 39$ and $369 \pm$ $44 \mathrm{pmol} / \mathrm{l}(P<0.06)$ respectively. Concomitant glucose infusion rates were significantly lower in affected MODY3 subjects $(5.73 \pm 2.19 \mathrm{mg} / \mathrm{kg} \mathrm{BW}$ per min) than in controls $(9.54 \pm 3.04 \mathrm{mg} / \mathrm{kg} \mathrm{BW}$ per min; $P<0.02)$. Individual ISIs computed from hyperinsulinemic euglycemic clamps or from hyperglycemic clamps are shown in Fig. 3. Average values were $21.8 \pm 8.5$ and $30.2 \pm 9.8 \mu \mathrm{l} / \mathrm{kg}$ BW per min per $\mathrm{pmol} / \mathrm{l}$ insulin $(P<0.07)$ for affected MODY3 and control subjects respectively, and $25.8 \pm 7.3 \mu \mathrm{l} / \mathrm{kg} \mathrm{BW}$ per min per $\mathrm{pmol} / \mathrm{l}$ insulin for unaffected MODY3 subjects.

\section{Discussion}

The present study shows that affected MODY3 subjects with DM or IGT present a severe defect of insulin secretion in response to glucose and arginine. Both the first-phase insulin secretion in response to glucose, assessed by IVGTT, and the second-phase insulin secretion, assessed by the hyperglycemic clamp, were substantially decreased (Tables 3 and 4). The amount of insulin secreted during the IVGTT and the hyperglycemic clamp by affected MODY3 subjects was less than 27 and 23\% respectively of the amount secreted by the control subjects during these two tests. Furthermore, the increase in the amount of insulin secreted in response to arginine in affected MODY 3 subjects was less than $32 \%$ of that observed in control subjects. Defects of insulin secretion were also detected in unaffected MODY3 subjects with NGT. The first-phase insulin secretion in response to glucose was well preserved, but the second phase, assessed by the hyperglycemic clamp was variably decreased in these subjects. The amount of insulin secreted during the 
Table 4 Summary of observed defects in MODY3 subjects. Computations performed with log-transformed data: N: value higher than 1 S.D. below the mean of controls; $\downarrow$ : value between 1 and 2 s.D. below the mean of controls; $\downarrow$ : value lower than 2 s.D. below the mean of controls; D: delayed response.

\begin{tabular}{|c|c|c|c|c|c|c|}
\hline Subject & $\begin{array}{c}\text { Glucose tolerance } \\
\text { status }\end{array}$ & $\begin{array}{c}\text { OGTT } \\
\text { (insulin secretion) }\end{array}$ & IGTT & $\begin{array}{l}\text { Hyperglycemic } \\
\text { clamp }\end{array}$ & $\underset{\text { test }}{\text { Arginine }}$ & $\begin{array}{l}\text { Insulin } \\
\text { sensitivity }^{\mathrm{a}}\end{array}$ \\
\hline M3\#1 & DM & $\downarrow$ & $\downarrow \downarrow$ & $\downarrow \downarrow$ & $\downarrow \downarrow$ & $\downarrow \downarrow$ \\
\hline M3\#2 & DM & $\downarrow$ & $\downarrow \downarrow$ & - & - & $\downarrow$ \\
\hline M3\#3 & DM & $\downarrow$ & $\downarrow \downarrow$ & $\downarrow \downarrow$ & $\downarrow \downarrow$ & $\downarrow$ \\
\hline M3\#4 & DM & $\downarrow$ & $\downarrow \downarrow$ & $\downarrow \downarrow$ & $\downarrow \downarrow$ & $\downarrow$ \\
\hline M3\#5 & DM & - & $\downarrow \downarrow$ & $\downarrow \downarrow$ & $\downarrow \downarrow$ & - \\
\hline M3\#6 & IGT & $\downarrow$ & $\downarrow \downarrow$ & $\downarrow \downarrow$ & $\downarrow \downarrow$ & $\mathrm{N}$ \\
\hline M3\#7 & IGT & $\mathrm{N}$ & $\downarrow \downarrow$ & $\downarrow \downarrow$ & $\mathrm{N}, \mathrm{D}$ & $\mathrm{N}$ \\
\hline M3\#8 & NGT & $\mathrm{N}$ & $\mathrm{N}$ & $\downarrow \downarrow$ & $\mathrm{N}, \mathrm{D}$ & $\mathrm{N}$ \\
\hline M3\#9 & NGT & - & $\mathrm{N}$ & $\mathrm{N}$ & - & $\downarrow$ \\
\hline M3\#10 & NGT & $\mathrm{N}$ & $\mathrm{N}$ & $\mathrm{N}$ & $\mathrm{N}, \mathrm{D}$ & $\mathrm{N}$ \\
\hline
\end{tabular}

${ }^{a}$ ISI computed from euglycemic hyperinsulinemic clamp data, except for subjects M3\#9 and M3\#10, for whom it was computed from hyperglycemic clamp data.

hyperglycemic clamp by the three unaffected MODY3 subjects was 40,69 and $79 \%$ of the amount secreted by the control subjects. Insulin secretion in response to arginine in the two unaffected MODY3 subjects who were tested, although quantitatively similar to that observed in control subjects, presented an abnormal temporal pattern. As shown in Fig. 2, the insulin secretion response was delayed and the return to basal (pre-arginine) levels was slow. This pattern of sustained response with slow return to basal levels was also observed in the affected MODY3 subjects with IGT and to a lesser extent in the affected MODY3 subjects with DM (data not shown). It is noteworthy that the response to the IVGTT was not consistently delayed in these subjects (Fig. 1).

The pathophysiological mechanisms leading to these defects remain unknown. It is interesting that severely impaired insulin secretory responses to glucose and arginine were also observed in perfused pancreas and perifused islets from HNF- $1 \alpha$-deficient mice (34). However, these animals also suffer from severe energy and water wasting due to renal proximal tubular dysfunctions, with massive urinary glucose and amino acid loss (35) while these renal defects are either absent or much milder in MODY3 subjects (36). Impaired insulin secretion in response to arginine in mice and man would be consistent with a defect distal to the mechanisms of glucose sensing of beta-cells (37), and/or with a reduction in the beta-cell mass $(38,39)$. Pancreatic histology shows reduced beta-cell mass in HNF- $1 \alpha$-deficient mice, which is, however, proportional to the reduction in mouse total BW (34). Thus, it is unclear whether the decreased insulin secretory response to arginine observed in mice and man is related to a reduction in beta-cell mass. It is noteworthy that insulin mRNA levels in the beta-cells of HNF-1 $\alpha$ deficient mice were normal (34), suggesting that the secretory defects in response to glucose and arginine are not related to a direct effect of HNF-1 $\alpha$ on the insulin gene.
Our results are in agreement with those observed in response to graded i.v. glucose infusions in a group of American, English and French diabetic and nondiabetic MODY3 subjects (18). ISRs were decreased in the diabetic subjects over a broad range of glucose concentration. In non-diabetic MODY3 subjects, ISRs were similar to those of control subjects at plasma glucose levels lower than $8 \mathrm{mmol} / \mathrm{l}$, but were significantly less than in controls at higher glucose levels, although individual results were heterogeneous. Interestingly, this pattern of decreased insulin secretion at high but not at low glucose levels was also observed in non-diabetic MODY1 subjects (40). As HNF- $4 \alpha$ is an upstream regulator of HNF-1 $\alpha$ expression (41), these two forms of MODY might share pathophysiological mechanisms. Decreased insulin secretion in response to OGTT and IVGTT were also reported in diabetic and non-diabetic Finish MODY3 subjects (19). Interestingly, a 2- to 4-fold increase in insulin secretion, as compared with controls, in response to i.v. loads of glucose (IVGTT), tolbutamide or glucagon was reported by Hansen and co-workers in a non-diabetic Danish carrier of the P447L mutation (42). The authors suggest that hyperexcitability of beta-cells to i.v. secretagogues may be associated with the pre-diabetic stages of the disease. We have not observed such hyperexcitability of betacells in the three unaffected MODY3 subjects with NGT that we have studied (Table 3), who all carry different mutations.

The results observed in affected and unaffected MODY 3 subjects contrast with those observed in diabetic MODY2 subjects, where first-phase insulin secretion and response to arginine are usually well preserved (Figs 1 and 2). Indeed, the beta-cell defect of MODY2 subjects seems to be primarily related to a glucosesensing defect leading to an increase in the blood glucose threshold that triggers insulin secretion (12), and a right shift in the dose-response curve of glucoseinduced insulin secretion (11), with an average 60\% reduction in insulin secretion for a given glucose level. 
The insulin secretion defect associated with GCK mutations is much less severe than that associated with $H N F-1 \alpha$ mutations. Diabetic MODY2 subjects secrete as much insulin as affected MODY3 subjects with IGT during a hyperglycemic clamp (Table 3), which supports the view that the GCK defect in the liver is an important contributor to the chronic hyperglycemia of MODY2 (13).

Insulin sensitivity was decreased in affected MODY3 subjects with DM and in one unaffected MODY3 subject with NGT who also presented with obesity (Table 4). A primary defect in insulin sensitivity associated with the HNF-1 $\alpha$ mutations should be detected before the development of chronic hyperglycemia, which was not the case in four MODY3 subjects with IGT or NGT. Insulin sensitivity was not decreased either in six lean Finish non-diabetic MODY3 subjects (19). Moreover, the study of five diabetic relatives of subject M3\#9 from the Swiss family FS4 showed decreased stimulation of glucose utilization, oxidation and non-oxidative glucose disposal, as well as blunted suppression of endogenous production (43); these defects were shown to be related to the endogenous insulinopenia. Taken together these data are most consistent with the conclusion that the insulin resistance observed in diabetic MODY 3 subjects is secondary to the pancreatic deficiency and/or resulting hyperglycemia. In this regard, Herman and co-workers assessed insulin secretion and insulin sensitivity in diabetic and non-diabetic MODY1 subjects (44). Similar insulin secretion abnormalities were observed in diabetic and non-diabetic subjects, while only some of the diabetic subjects had decreased insulin sensitivity. Polonsky and co-workers (45) used a mathematical model of the insulin-glucose feedback mechanisms and the data of the dose-response curve glucose/ISR to simulate the effects of variations in insulin sensitivity on glucose tolerance in non-diabetic MODY1 subjects and in their mutation-negative relatives. They observed that a moderate decrease in insulin sensitivity $(40 \%)$ was associated with transition from NGT to overt diabetes in non-diabetic MODY1 subjects, given their insulin secretion defect, while no such effect was observed in the mutation-negative relatives. Studies of insulin sensitivity in a cohort of 125 MODY2 subjects showed that insulin resistance was associated with the deterioration of the glucose tolerance status (46): insulin sensitivity was higher in NGT, intermediate in IGT, and lower in diabetic MODY2 subjects. Taken together, these data suggest that, although not a primary event in the development of hyperglycemia of MODY, insulin resistance modulates the glucose tolerance and contributes as an additional mechanism for the chronic hyperglycemia.

In summary, affected MODY3 subjects with DM or IGT present a severe defect of insulin secretion in response to glucose and arginine. A less severe defect was also observed in unaffected MODY3 subjects with NGT, suggesting that these individuals carry a high risk for developing NIDDM. The pathophysiological mechanisms and the target genes of $\mathrm{HNF}-1 \alpha$ responsible for this defect remain unknown. They might be related to the glucose metabolism, to mechanisms that are distal to those of glucose sensing in beta-cells, and/or to a decrease in beta-cell mass. The MODY3 and MODY2 subtypes present different clinical and insulin secretion profiles, suggesting that even in relatively homogenous subtypes of NIDDM such as MODY, the genetic characterization may reveal specific metabolic profiles.

\section{Acknowledgements}

MV and MEP contributed equally to this work. We thank the patients and their families for their co-operation, Philippe Gallina for managing the contact with the patients, Monique Tendron for nursing assistance, and Prof. Christian Boitard and the nursing staff of the Service d'Immunologie Clinique, Hôpital Necker, Paris. This work was partially supported by grants from the French Ministry for Research and Technology, European Union (Biomed 2), and Institut Lilly France (Contrat de Recherche Lilly-ALFEDIAM). The ISEC software was kindly provided by Dr Roman Hovorka (Centre for Measurement and Information in Medicine, Department of Systems Science, City University, London, UK).

\section{References}

1 Froguel P, Vaxillaire M \& Velho G. Genetic and metabolic heterogeneity of maturity onset diabetes of the young. Diabetes Reviews 19975 123-130.

2 Yamagata K, Furuta H, Oda O, Kaisaki PJ, Menzel S, Cox NJ et al. Mutations in the hepatocyte nuclear factor 4 alpha gene in maturity-onset diabetes of the young (MODY1). Nature 1996384 458-460.

3 Bulman MP, Dronsfield MJ, Frayling T, Appleton M, Bain SC, Ellard S et al. A missense mutation in the hepatocyte nuclear factor 4 alpha gene in a UK pedigree with maturity-onset diabetes of the young. Diabetologia 199740 859-862.

4 Froguel P, Zouali H, Vionnet N, Velho G, Vaxillaire M, Sun F et al. Familial hyperglycemia due to mutations in glucokinase: definition of a subtype of diabetes mellitus. New England Journal of Medicine 1993328 697-702.

5 Velho G, Blanché H, Vaxillaire M, Bellanné-Chantelot C, Pardini $\mathrm{VC}$, Timsit J et al. Identification of 14 new glucokinase mutations and description of the clinical profile of 42 MODY-2 families. Diabetologia 199740 217-224.

6 Yamagata K, Oda N, Kaisaki PJ, Menzel S, Furuta H, Vaxillaire M et al. Mutations in the hepatocyte nuclear factor 1 alpha gene in maturity-onset diabetes of the young (MODY3). Nature 1996384 455-458.

7 Vaxillaire M, Rouard M, Yamagata K, Oda N, Kaisaki PJ, Boriraj VV et al. Identification of nine novel mutations in the hepatocyte nuclear factor 1 alpha gene associated with maturityonset diabetes of the young (MODY3). Human Molecular Genetics $19976583-586$.

8 Stoffers DA, Ferrer J, Clarke WL \& Habener JF. Early-onset type 2 diabetes mellitus (MODY4) linked to IPF1. Nature Genetics 1997 $17138-139$.

9 Horikawa Y, Iwasaki N, Hara M, Furuta H, Hinokio Y, Cockburn BN et al. Mutation in hepatocyte nuclear factor-1 $\beta$ gene (TCF2) associated with MODY. Nature Genetics 199717 384-385. 
10 Chévre JC, Hani EH, Boutin P, Vaxillaire M, Blanché H, Vionnet N et al. Mutation screening in 18 caucasian families suggests the existence of other MODY genes. Diabetologia 199841 1017-1023.

11 Byrne MM, Sturis J, Clément K, Vionnet N, Pueyo ME, Stoffel M et al. Insulin secretory abnormalities in subjects with hyperglycemia due to glucokinase mutations. Journal of Clinical Investigation 199493 1120-1130.

12 Velho G, Froguel P, Clément K, Pueyo ME, Rakotoambinina B, Zouali $\mathrm{H}$ et al. Primary pancreatic beta-cell secretory defect caused by mutations in the glucokinase in kindreds of maturity onset diabetes of the young. Lancet $1992340444-448$.

13 Velho G, Petersen KF, Perseghin G, Hwang J-H, Rothman DL, Pueyo ME et al. Impaired hepatic glycogen synthesis in glucokinase-deficient (MODY-2) subjects. Journal of Clinical Investigation 199698 1755-1761.

14 Fajans SS, Bell GI, Bowden DW, Halter JB \& Polonsky KS. Maturityonset diabetes of the young. Life Science 199455 413-422.

15 Velho G, Vaxillaire M, Boccio V, Charpentier G \& Froguel P. Diabetes complications in NIDDM kindreds linked to the MODY-3 locus on chromosome 12q. Diabetes Care 199619 915-919.

16 Tronche F \& Yaniv M. HNF1, a homeoprotein member of the hepatic transcription regulatory network. Bioessays 199214 579-587.

17 Emens LA, Landers DW \& Moss LG. Hepatocyte nuclear factor $1 \alpha$ is expressed in a hamster insulinoma line and transactivates the rat insulin I gene. Proceedings of the National Academy of Sciences of the USA $1992897300-7304$.

18 Byrne MM, Sturis J, Menzel S, Yamagata K, Fajans SS, Dronsfield MJ et al. Altered insulin secretory responses to glucose in diabetic and nondiabetic subjects with mutations in the diabetes mellitus susceptibility gene MODY on chromosome 12 Diabetes $1996451503-1510$.

19 Lehto M, Tuomi T, Mahtani MM, Widen E, Forsblom C, Sarelin L et al. Characterization of the MODY3 phenotype-early-onset diabetes caused by an insulin secretion defect. Journal of Clinical Investigation 199799 582-591.

20 Froguel P, Velho G, Cohen D \& Passa P. Strategies for the collection of sibling-pair data for genetic studies in type 2 (non insulindependent) diabetes mellitus. Diabetologia 199134685.

21 WHO Study Group on Diabetes Mellitus. World Health Organization Technical Report Series 1985 No. 727.

22 Pueyo ME, Clement K, Vaxillaire M, Passa P, Froguel P, Robert JJ et al. Arginine-induced insulin release in glucokinase-deficient subjects. Diabetes Care 199417 1015-1021.

23 Velho G, Byrne MM, Clément K. Sturis J. Pueyo ME, Blanché H et al. Clinical phenotypes, insulin secretion and insulin sensitivity in kindreds with maternally inherited diabetes and deafness due to mitochondrial tRNA ${ }^{\text {Leu (UUR) }}$ gene mutation. Diabetes 1996 45 478-487.

24 DeFronzo RA, Tobin JD \& Andres R. Glucose clamp technique: a method for quantifying insulin secretion and resistance. American Journal of Physiology 1979237 E214-E223.

25 Ward WK, Halter JB, Beard JC \& Porte D Jr. Adaptation ofB-and A-cell function during prolonged glucose infusion in human subjects. American Journal of Physiology 1984246 E405-E411.

26 Stone LM, Kahn SE, Fujimoto WY, Deeb SS \& Porte D. A variation at position -30 of the beta-cell glucokinase gene promoter is associated with reduced beta-cell function in middle-aged Japanese-American men. Diabetes $199645422-428$.

27 Philipps DIW, Clark PM, Hales CN \& Osmod C. Understanding oral glucose tolerance: comparison of glucose or insulin measurements during the oral glucose tolerance test with specific measurements of insulin resistance and insulin secretion. Diabetic Medicine $199411286-292$

28 Eaton RP, Allen RC, Schade DS, Erickson KM \& Standefer J. Prehepatic insulin production in man: kinetic analysis using peripheral connecting peptide behavior. Journal of Clinical Endocrinology and Metabolism 198051 520-528.
29 Hovorka R. A computer program to reconstruct insulin secretion. Diabetologia 199336 (Suppl 1) A68.

30 Van Cauter E, Mestrez F, Sturis J \& Polonsky KS. Estimation of insulin secretion rates from C-peptide levels. Comparison of individual and standard kinetic parameters for C-peptide clearance. Diabetes $199241368-377$.

31 Verdonk C, Rizza R \& Gerich J. Effects of plasma glucose concentration on glucose utilization and glucose clearance in normal man. Diabetes $198130535-537$.

32 Mitrakou A, Vuorinen-Markkola H, Raptis G, Toft I, Mokan M, Strumph P et al. Simultaneous assessment of insulin secretion and insulin sensitivity using a hyperglycemic clamp. Journal of Clinical Endocrinology and Metabolism 199275 379-382.

33 Kramer CY. Extension of multiple range tests to group means with unequal number of replications. Biometrics 195612 309-310.

34 Pontoglio M, Sreenan S, Roe M, Pugh W, Ostrega D, Doyen A et al. Defective insulin secretion in hepatocyte nuclear factor $1-\alpha$ deficient mice. Journal of Clinical Investigation 1998101 2215-2222.

35 Pontoglio M, Barra J, Hadchouel M, Doyen A, Kress C, Poggi Bach J et al. Hepatocyte nuclear factor 1 inactivation results in hepatic dysfunction, phenylketonuria, and renal Fanconi syndrome. Cell $199684572-585$.

36 Velho G, Benqué -Blanchet F, Vaxillaire M, Pontoglio M, Froguel P, Friedlander $\mathrm{G}$ et al. Renal proximal tubular defects associated to the MODY3 phenotype. Diabetologia 199841 (Suppl 1) A108.

37 Blachier F, Leclercq-Meyer V, Marchand J, Woussen-Colle MC, Mathias PCF, Sener A et al. Stimulus-secretion coupling of arginine-induced insulin release. Functional response of islets to L-arginine and ornithine. Biochimica et Biophysica Acta 1989 1013 144-151.

38 Ward WK, Wallum BJ, Beard JC, Taborsky GJ Jr \& Porte D Jr. Reduction of glycemic potentiation. Sensitive indicator of b-cell loss in partially pancreatectomized dogs. Diabetes 198837 723-729.

39 Seaquist ER \& Robertson RP. Effects of hemipancreatectomy on pancreatic alpha and beta cell function in healthy human donors. Journal of Clinical Investigation 199289 1761-1766.

40 Byrne MM, Sturis J, Fajans SS, Ortiz FJ, Stoltz A, Stoffel M et al. Altered insulin secretory responses to glucose in subjects with a mutation in the MODY1 gene on chromosome 20. Diabetes 1995 44 699-704.

41 Kuo CJ, Conley PB, Chen L, Sladek FM, Darnell JE \& Crabtree GR. A transcriptional hierarchy is involved in mammalian cell-type specification. Nature $1992355457-461$.

42 Hansen T, Eiberg H, Rouard M, Vaxillaire M, Moller AM, Rasmussen SK et al. Novel MODY3 mutations in the hepatocyte nuclear factor-1 alpha gene: evidence for a hyperexcitability of pancreatic beta-cells to intravenous secretagogues in a glucose-tolerant carrier of a P447L mutation. Diabetes $199746726-730$.

43 Surmely JF, Guenat E, Philippe J, Dussoix P, Schneiter P, Temler E et al. Glucose utilization and production in patients with maturity-onset diabetes of the young caused by a mutation of the hepatocyte nuclear factor-1 alpha gene. Diabetes 199847 1459-1463.

44 Herman WH, Fajans SS, Ortiz FJ, Smith MJ, Sturis J, Bell GI et al. Abnormal insulin secretion, not insulin resistance, is the genetic or primary defect of mody in the RW pedigree. Diabetes 199443 $40-46$.

45 Polonsky KS, Sturis J \& Bell GI. Non-insulin-dependent diabetes mellitus: a genetically programmed failure of the beta cell to compensate for insulin resistance. New England Journal of Medicine $1996334777-783$.

46 Clément K, Pueyo ME, Vaxillaire M, Rakotoambinina B, Thuillier F, Passa P et al. Assessment of insulin sensitivity in glucokinasedeficient subjects. Diabetologia 199639 82-90.

Received 1 March 1999

Accepted 18 August 1999 